\title{
CAPN10 SNP-19 is Associated with Susceptibility of Type 2 Diabetes Mellitus: A Javanese Case-control Study
}

\author{
Yanuarita Tursinawati ${ }^{1, *}$, Rifqi Fauzan Hakim², Afiana Rohmani ${ }^{1}$, Arum Kartikadewi ${ }^{1}$,Ferry Sandra ${ }^{3}$ \\ ${ }^{1}$ Department of Biomedics, Faculty of Medicine, Universitas Muhammadiyah Semarang, Jl. Kedungmundu Raya No.18, Semarang, Indonesia \\ ${ }^{2}$ Undergraduate Program, Faculty of Medicine, Universitas Muhammadiyah Semarang, Jl. Kedungmundu Raya No.18, Semarang, Indonesia \\ ${ }^{3}$ Department of Biochemistry and Molecular Biology, Division of Oral Biology, Faculty of Dentistry, Universitas Trisakti, Jl. Kyai Tapa No.260, \\ Jakarta, Indonesia \\ *Corresponding author. E-mail: yanuarita_tursina@unimus.ac.id
}

Received date: Sep 20, 2019; Revised date: Feb 21, 2020; Accepted date: Mar 5, 2020

\section{Abstract}

$\mathrm{B}$ ACKGROUND: The health data of Central Java, Indonesia showed that diabetes mellitus (DM) was the second most increasing non-communicable disease in the province. More than 20 genes have been reported to be associated with DM. Calpain-10 (CAPN10) polymorphism has been reported to be associated with Type 2 Diabetes Mellitus (T2DM). However, the association between CAPN10 single nucleotide polymorphism (SNP)19 and T2DM among Javanese ethnics has never been reported. Therefore, this study was conducted to investigate the association.

METHODS: After fasting for 8 hours, blood samples were drawn from veins of 107 T2DM and 107 non diabetic subjects. A half of the drawn blood was collected for identification of CAPN10 SNP-19, and another half for measuring triglycerides and fasting blood glucose (FBG). Identification of CAPN10 SNP-19 was performed with polymerase chain reaction (PCR) method, while measurement of triglycerides and FBG with colorimetric enzymatic method.

RESULTS: The number of T2DM Javanese subjects with $2 \mathrm{R} / 3 \mathrm{R}$ and $3 \mathrm{R} / 3 \mathrm{R}$ CAPN10 SNP-19 genotypes was significantly higher than the number of T2DM Javanese subjects with $2 \mathrm{R} / 2 \mathrm{R}$ genotype $(p=0.002)$. When each number of $2 R / 3 R$ and $3 R / 3 R$ T2DM subjects was compared with the number of $2 R / 2 R$ T2DM subjects, the number of $2 R / 3 R$ T2DM subjects was significantly higher than the number of $2 \mathrm{R} / 2 \mathrm{R}$ T2DM subjects $(p=0.000)$.

CONCLUSION: Javanese subjects with $2 \mathrm{R} / 3 \mathrm{R}$ and $3 \mathrm{R} / 3 \mathrm{R}$ CAPN10 SNP19 genotypes might have susceptibility of T2DM.

KEYWORDS: Calpain-10, CAPN10, polymorphism, type 2 diabetes mellitus, triglycerides, fasting blood glucose

Indones Biomed J. 2020; 12(2): 109-14

\section{Introduction}

Indonesian lifestyle is continuously changing, which causes the shift from infectious to degenerative diseases, such as diabetes mellitus (DM). DM is metabolic disorder characterized by progressive loss or dysfunction of pancreatic $\beta$ cell.(1) The health data of Central Java, Indonesia in 2016 showed that DM was the second most increasing non-communicable disease, after hypertension, with a rate of $16.42 \%$. In 2006, 972 new DM cases were found. Its causes were attributed to age, obesity, fat distribution, lack of physical activity, and genetic factors.

(2) More than 20 genes have been reported to be associated with DM. One of the genes is Calpain-10 (CAPN10), which is located on chromosome 2q37.3 and encodes CAPN10 protein. A previous study showed that CAPN10 polymorphism was associated with Type 2 DM (T2DM). $(3,4)$ Calpain-10 was reported to play a role in the insulin vesicle exocytosis process of pancreatic $\beta$ cell and insulinstimulated Glucose Transporter 4 (GLUT4) translocation of muscle cell and adipocyte.(5) 
Insulin resistance, a condition where targeted cells fail to respond to the insulin stimulus under normal concentration, which can be occurred among patients with T2DM. There is also metabolism dysfunctional among these patients. Decrease in insulin occurred in the fat tissues, leading to a decrease in lipogenesis and an increase in lipolysis. Then this will lead to the dyslipidemia, condition marked by the increase of triglycerides and Low-Density Lipoprotein (LDL), with a decrease in High-Density Lipoprotein (HDL).(6)

Some studies proved that CAPN10 polymorphism increased the risk of insulin resistance and the level of free fatty acid (FFA). Obese subjects with CAPN10 single nucleotide polymorphism (SNP)-43 and G/G genotype were reported to have significant triglyceride level.(7) High level of plasma saturated fatty acids and low glucose effectiveness were also found in metabolic syndrome subjects with $\mathrm{G} / \mathrm{G}$ genotype.(8) A research on normoglycemic individuals proved that subjects with CAPN10 SNP-19 or Del/Ins 19 (rs3842570) consisting of $2 \mathrm{R} / 3 \mathrm{R}$ and $3 \mathrm{R} / 3 \mathrm{R}$ genotypes had significant lower HDL-C levels compared to the $2 \mathrm{R} / 2 \mathrm{R}$ genotype.(9) T2DM subjects with homozygous 3R/3R genotypes had a significant higher cholesterol level.(10) CAPN10 SNP-19 occurred when 2 or 3 repetitions of $32 \mathrm{bp}$ in intron-6.

The involvement of CAPN10 SNP-19 towards the triglycerides level of Javanese with T2DM has never been reported. Data from Survey of Aspek Kehidupan Rumah Tangga Indonesia (Sakerti) or Indonesia Family Life Survey (IFLS) in 2007 showed that Javanese and Madurese ethnic groups had the highest rates of diabetes in Indonesia, by $78.4 \%$.(11) Therefore, this study was conducted to investigate the association between CAPN10 SNP-19 and T2DM among Javanese ethnics.

\section{Methods}

\section{Subject Selection and Sample Collection}

A case control study was conducted in 107 T2DM and 107 non-diabetic selected subjects. All subjects were recruited from the Primary Health Care Centre in Semarang. The inclusion criteria were Javanese ethnic, 30-65 years old and having no history of cardiovascular disease. Prior to the selection, all subjects signed the informed consent. After fasting for 8 hours, $5 \mathrm{~mL}$ of blood samples were drawn from veins of the selected subjects. A half of the drawn blood was collected for identification of CAPN10 SNP-19, while another half for measuring triglycerides and fasting blood glucose (FBG). The study protocol was approved by Ethics Committee of Faculty of Medicine, Universitas Muhammadiyah Semarang (No. 064/EC/FK/2019).

\section{Identification of CAPN10 SNP-19}

DNA was isolated from the whole blood using GeneJET Genomic DNA Purification Kit (Catalog \#K0721, Thermo Fisher Scientific, Waltham, MA, USA). The identification of CAPN10 SNP-19 was conducted by peqSTAR 2X Thermocyclers (VWR, Lutterworth, UK) with DreamTaq Green PCR Master Mix (2X) (Thermo Fisher Scientific). Based on previous report, forward primer 5'-GTTTGGTTCTCTTCAGCGTGGAG-3' and reverse primer 5'-ATGAACCCTGGCAGGGTCTAAG-3' were used.(12) PCR was set as follows: the pre-denaturation condition at $95^{\circ} \mathrm{C}$ for $4 \mathrm{~min}$, the 35 cycling condition of $95^{\circ} \mathrm{C}$ for $1 \mathrm{~min}, 60^{\circ} \mathrm{C}$ for $30 \mathrm{sec}$, and $72^{\circ} \mathrm{C}$ elongation for $1 \mathrm{~min}$, and the final extension at $72^{\circ} \mathrm{C}$ for $10 \mathrm{~min}$. PCR product was visualized with $2 \%$ of agarose gel. The electrophoresis result showed $155 \mathrm{bp}$ of allele $2 \mathrm{R}$ ( 2 repeats of $32 \mathrm{bp} /$ wild type) and $187 \mathrm{bp}$ of allele 3R (3 repeats of $32 \mathrm{bp} /$ variant of CAPN10 SNP-19).

\section{Triglycerides and FBG Measurements}

Serum of the blood was measured using Triglycerides FS (DiaSys Diagnostic Systems, Waterbury, CT, USA) and Glucose GOD FS (DiaSys Diagnostic Systems) based on the colorimetric enzymatic method with glycerol-3-phosphateoxidase and glucose oxidase. Procedure and calculation were performed according to the kit inserts. Briefly, serum was mixed with each provided reagent, homogenized and incubated at room temperature for $10 \mathrm{~min}$. Then the reaction was read with spectrophotometer at absorbance of $500 \mathrm{~nm}$ within $60 \mathrm{~min}$.

\section{Statistical Analysis}

Data was calculated using SPSS for Windows version 15.0 (SPSS Inc., Chicago, IL, USA). Independent $\mathrm{T}$ and Chi-square tests were applied based on variable scale. The $p<0.05$ was set as significant.

\section{Results}

Subject characteristics of T2DM and control subjects are shown in Table 1. Age, body mass index (BMI), systolic blood pressure (SBP), triglycerides and FBG of T2DM subjects were significantly $(p<0.05)$ higher than the control subjects (Table 1). 
Table 1. T2DM (n=107) and control $(n=107)$ subject characteristics.

\begin{tabular}{lccc}
\hline \multicolumn{1}{c}{ Variable } & Control & T2DM & $\boldsymbol{p}$-value* \\
\hline Age (year) & $30-60$ & $40-69$ & 0.000 \\
Gender (n) & & & \\
$\quad$ Male & 33 & 35 & - \\
$\quad$ Female & 74 & 72 & - \\
BMI $\left(\mathrm{kg} / \mathrm{m}^{2}\right)$ & $15.83-35.41$ & $18.90-36.52$ & 0.017 \\
SBP $(\mathrm{mm} / \mathrm{Hg})$ & $82-158$ & $100-200$ & 0.000 \\
DBP $(\mathrm{mm} / \mathrm{Hg})$ & $57-114$ & $47-128$ & 0.113 \\
Triglycerides $(\mathrm{mg} / \mathrm{dL})$ & $4.70-264.28$ & $97.87-310.09$ & 0.000 \\
FBG $(\mathrm{mg} / \mathrm{dL})$ & $62-123$ & $60-374$ & 0.000 \\
\hline
\end{tabular}

*Analyzed with Independent T-test.

PCR electrophoresis results are shown in Figure 1. Each $\mathrm{C}$ and $\mathrm{D}$ lane showed a $155 \mathrm{bp}$ band, suggesting a wild-type homozygous $(2 \mathrm{R} / 2 \mathrm{R})$ genotype. Each $\mathrm{M}, \mathrm{N}$, $\mathrm{O}$ and $\mathrm{P}$ lane showed a 187 bp band, suggesting a variant homozygous (3R/3R) genotype. Meanwhile, each A, B, E, F, G, H, I, J, K and L lane showed 2 bands, 155 bp and 187 bp, suggesting a variant heterozygous $(2 \mathrm{R} / 3 \mathrm{R})$ genotype. In the T2DM group, the highest genotype frequency was the $2 \mathrm{R} / 3 \mathrm{R}$ genotype with a total of 84 subjects (79\%).

The number of T2DM Javanese subjects with $2 \mathrm{R} / 3 \mathrm{R}$ and 3R/3R CAPN10 SNP-19 genotypes was significantly higher than the number of T2DM Javanese subjects with $2 \mathrm{R} / 2 \mathrm{R}$ genotype $(p=0.002)$ (Table 2$)$. When each number of $2 R / 3 R$ and $3 R / 3 R$ T2DM subjects was compared with the number of $2 R / 2 R$ T2DM subjects, the number of $2 R / 3 R$ T2DM subjects was significantly higher than the number of $2 \mathrm{R} / 2 \mathrm{R}$ T2DM subjects $(p=0.000$ ) (Table 3 ). Meanwhile, the number of 3R/3R T2DM subjects was not significantly higher than the number of $2 R / 2 R$ T2DM subjects.

$\mathrm{T} 2 \mathrm{DM}$ and control subjects characteristics as shown in Table 1 were grouped based on the $2 R / 2 R$ and $2 R / 3 R+$ $3 R / 3 R$ genotypes. However, all parameters including age,
BMI, SBP, diastolic blood pressure (DBP), triglycerides and FBG, did not show any significant difference between the groups (Table 4). Although not significant, BMI, triglycerides and $F B G$ of $2 R / 3 R+3 R / 3 R$ group of $T 2 D M$ subjects were higher than the BMI, triglycerides and FBG of $2 \mathrm{R} / 2 \mathrm{R}$ group of $\mathrm{T} 2 \mathrm{DM}$ subjects. In accordance, triglycerides and $F B G$ of $2 R / 3 R+3 R / 3 R$ group of control subjects were also higher than the triglycerides and $F B G$ of $2 R / 2 R$ group of control subjects, although not significant.

\section{Discussion}

CAPN10 polymorphism has been reported to have an association with the vulnerability of T2DM. The retardation of CAPN10 is capable of decreasing insulin secretion in pancreatic cells.(13) A study on pancreatic islet of CAPN10 knockout mice proved that the diminished of CAPN10 altered insulin secretion through microtubule associated protein 1 (MAP1) family.(14) CAPN10 cleavage MAP1 family protein into heavy and light chain so enhances its function to coordinate microtubule and actin filament. Decreased of

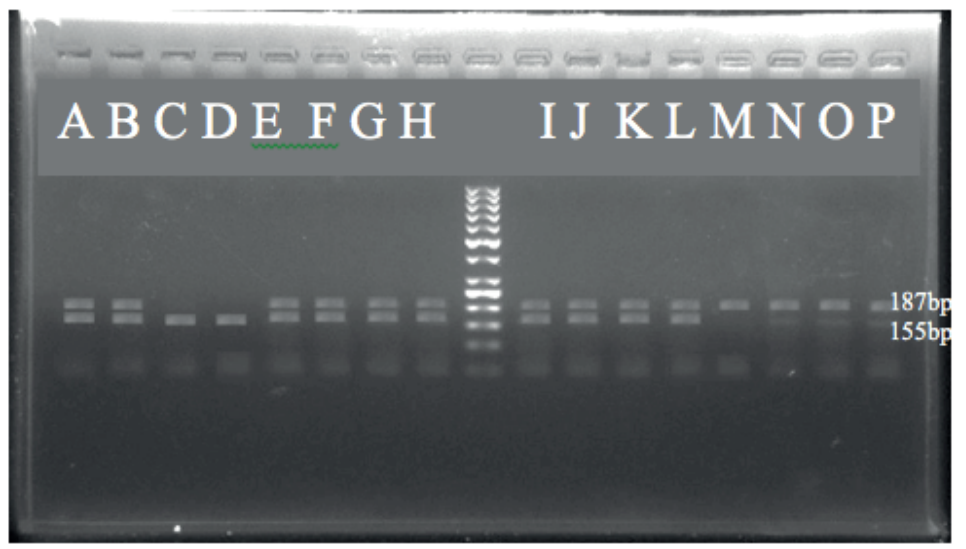

Figure 1. PCR electrophoresis results of wildtype/variant homozygous/heterozygous CAPN10 SNP-19 genotypes. A-L lanes: T2DM subjects, M-P lanes: control subjects. The 155 bp band: wildtype, $187 \mathrm{bp}$ band: variant. 
Table 2. The differences among the control and T2DM subjects number based on CAPN10 SNP-19 genotypes.

\begin{tabular}{lcccccc}
\hline \multirow{2}{*}{ Variable } & \multicolumn{2}{c}{ Subject } & \multirow{2}{*}{ p-value* } & OR & \multicolumn{2}{c}{ 95\% CI } \\
\cline { 2 - 3 } \cline { 6 - 7 } & Control & T2DM & & & Lower & Upper \\
\hline $2 \mathrm{R} / 3 \mathrm{R}+3 \mathrm{R} / 3 \mathrm{R}$ & $81(75.70 \%)$ & $98(91.59 \%)$ & 0.002 & 3.495 & 1.550 & 7.882 \\
$2 \mathrm{R} / 2 \mathrm{R}$ & $26(24.30 \%)$ & $9(8.41 \%)$ & & & & \\
\hline
\end{tabular}

*Analyzed with Chi-square test. OR: odd ratio, CI: confidence interval.

CAPN10 function effects of actin reorganization and insulin secretion from $\beta$ cell.

Current results showed that there was a significant difference between the number of T2DM Javanese subjects with $2 \mathrm{R} / 3 \mathrm{R}$ and $3 \mathrm{R} / 3 \mathrm{R} C A P N 10$ SNP-19 genotypes than the number of T2DM Javanese subjects with $2 \mathrm{R} / 2 \mathrm{R}$ genotype. This results suggested that CAPN10 SNP-19 genotypes was related to the incidence of T2DM. This finding was in line with a previous study on the Tunisian Arabs which showed that $\mathrm{T} 2 \mathrm{DM}$ subjects $2 \mathrm{R} / 3 \mathrm{R}$ genotype had significant higher risk than the T2DM subjects with $2 \mathrm{R} / 2 \mathrm{R}$ genotype.(12) Besides in Tunisia, another study in Mexico suggested that this polymorphism contributed in the incidence of T2DM as well.(15)

However, there was no association between the CAPN10 SNP-19 and the T2DM on Minangkabau ethnic group, even though this ethic is a part of Indonesia.(16) Another study in Gaza reported that the most frequent genotype of CAPN10 SNP-19 was 3R/3R.(10) Similar to Minangkabau, study in Gaza also showed no significant association between the CAPN10 SNP-19 and T2DM.

T2DM is not only caused by polymorphism factor, but also by lifestyle, gender and obesity.(14) Those suffering from this disease have dyslipidemia causing chronic metabolic disorders characterized by abnormal cytokine production, increased acute phase reactants, mediators, and activation of inflammatory factors.(17) Insulin resistance of T2DM is associated with high triglycerides and low HDL-C level although the relationship were still weak.(18) A study among population in China (Kazak, Ugyur and Han ethnic) also found that there was a relationship between triglycerides level and insulin resistance.(19) Insulin resistance seems to be closely related with inflammation caused by dietary fatty acids. It was hypothesized that there was accumulation of diacylglyceride (DAG) that inhibit insulin signaling and enhance endoplasmic reticulum stress and oxidative stress. (20) High fatty acid (especially Arachidonic acid/AA) produce 12-HETE which is very toxic to beta pancreas and leads to cell destruction.(21)

Current study also analyzed the association between CAPN10 SNP-19 with the level of FBG and triglycerides. The results showed FBG and triglycerides of both control and T2DM subjects with $2 R / 3 R+3 R / 3 R$ genotypes were higher than the subjects with $2 \mathrm{R} / 2 \mathrm{R}$ genotype, even though not significant. Another study showed that both FBG and triglycerides level didn't show a significant difference in each CAPN10 SNP-19 genotype.(22) However, other study noted that subjects with $2 \mathrm{R} / 2 \mathrm{R}$ and $2 \mathrm{R} / 3 \mathrm{R}$ genotypes had a significantly higher concentration of triglycerides than subjects with $3 \mathrm{R} / 3 \mathrm{R}$ genotype.(23)

The variation of CAPN10 has the ability to decrease the function of $\beta 3$ adrenoceptor and adipose cells of obese people.(24) The genetic variation of CAPN10 which was successfully identified to affect triglycerides level in obese people was $S N P-43 .(6)$ The obese subjects with $S N P-43$ $\mathrm{G} / \mathrm{G}$ had a significant lower concentration of triglycerides

Table 3. The differences among the control and T2DM subjects number based on CAPN10 SNP-19 genotypes.

\begin{tabular}{lccccccc}
\hline \multirow{2}{*}{ Genotype } & \multicolumn{2}{c}{ Subject } & p-value* & OR & \multicolumn{2}{c}{ 95\% CI } \\
\cline { 2 - 3 } & Control & T2DM & & Lower & Upper \\
\hline $2 \mathrm{R} / 2 \mathrm{R}$ & $26(24.30 \%)$ & $9(8.41 \%)$ & & & \\
$2 \mathrm{R} / 3 \mathrm{R}$ & $40(37.38 \%)$ & $84(78.50 \%)$ & 0.000 & 6.067 & 2.602 & 14.142 \\
$3 \mathrm{R} / 3 \mathrm{R}$ & $41(38.32 \%)$ & $14(13.09 \%)$ & 0.978 & 0.986 & 0.374 & 2.605 \\
\hline
\end{tabular}

*Analyzed with Chi-square test against 2R/2R genotype. OR: odd ratio, CI: confidence interval.. 
Table 4. The differences of subject characteristics based on CAPN10 SNP-19 genotypes.

\begin{tabular}{|c|c|c|c|c|c|c|}
\hline \multirow{2}{*}{ Variable } & \multicolumn{2}{|c|}{ Control } & \multirow{2}{*}{$p$-value* } & \multicolumn{2}{|c|}{ T2DM } & \multirow{2}{*}{$p$-value* } \\
\hline & $2 R / 2 R$ & $2 R / 3 R+3 R / 3 R$ & & $2 R / 2 R$ & $2 R / 3 R+3 R / 3 R$ & \\
\hline Age (year) & $44.23 \pm 1.96$ & $43.32 \pm 1.04$ & 0.672 & $57.11 \pm 1.87$ & $55.45 \pm 0.69$ & 0.480 \\
\hline BMI $\left(\mathrm{kg} / \mathrm{m}^{2}\right)$ & $25.10 \pm 0.79$ & $24.35 \pm 0.45$ & 0.410 & $24.07 \pm 0.82$ & $26.28 \pm 0.37$ & 0.079 \\
\hline $\mathrm{SBP}(\mathrm{mm} / \mathrm{Hg})$ & $119.42 \pm 3.27$ & $118.09 \pm 1.68$ & 0.703 & $142.00 \pm 7.27$ & $137.53 \pm 2.09$ & 0.539 \\
\hline DBP (mm/Hg) & $86.81 \pm 2.59$ & $83.05 \pm 1.22$ & 0.151 & $83.11 \pm 3.17$ & $82.17 \pm 1.09$ & 0.803 \\
\hline Triglycerides (mg/dL) & $81.37 \pm 6.61$ & $96.07 \pm 6.06$ & 0.198 & $166.38 \pm 20.18$ & $170.63 \pm 5.04$ & 0.811 \\
\hline FBG (mg/dL) & $93.08 \pm 2.87$ & $96.90 \pm 1.65$ & 0.253 & $125.67 \pm 9.62$ & $135.65 \pm 6.05$ & 0.623 \\
\hline
\end{tabular}

*Analyzed with Independent T-test.

compared to the obese subjects with allele A. Current study investigated one type of CAPN10 polymorphism merely. The risk of T2DM can be predicted more valid by investigating the combination of various $C A P N 10$ polymorphisms, such as $S N P-44, S N P-43$, and $S N P-63$. Therefore, further study is needed to investigate further those SNPs.

\section{Conclusion}

Javanese subjects with 2R/3R and 3R/3R CAPN10 SNP19 genotypes might have susceptibility of T2DM.

\section{Acknowledgements}

This study was funded by the Internal Research Foundation of Universitas Muhammadiyah Semarang and Universitas Negeri Semarang.

\section{References}

1. Chen C, Cohrs CM, Stertmann J, Bozsak R, Speier S. Human beta cell mass and function in diabetes : Recent advances in knowledge and technologies to understand disease pathogenesis. Mol Metab. 2017; 6: 943-57.

2. Dinas Kesehatan Provinsi Jawa Tengah. Profil Kesehatan Jawa Tengah 2017. Semarang: Dinas Kesehatan Provinsi Jawa Tengah; 2018.

3. Nam JS, Han JW, Lee SB, You JH, Kim MJ, Kang S, et al. Calpain-10 and adiponectin gene polymorphisms in Korean type 2 diabetes patients. Endocrinol Metab (Seoul). 2018; 33: 364-71.

4. Horikawa Y, Oda N, Cox NJ, Li X, Orho-melander M, Hara M, et al. Genetic variation in the gene encoding calpain-10 is associated with type 2 diabetes mellitus. Nat Genet. 2000; 26: 163-75.

5. Pánico P, Salazar AM, Burns AL, Ostrosky-Wegman P. Role of Calpain-10 in the development of diabetes mellitus and its complications. Arch Med Res. 2014; 45: 103-15.
6. Todingrante A, Arief M, Bahrun U, Sandra F. Study of low-grade chronic inflammatory markers in men with central obesity: cathepsin $\mathrm{S}$ was correlated with waist circumference. Indones Biomed J. 2013; 5: 115-20.

7. Carlsson E, Fredriksson J, Groop L, Ridderstråle M. Variation in the Calpain-10 gene is associated with elevated triglyceride levels and reduced adipose tissue messenger ribonucleic acid expression in obese Swedish subjects. J Clin Endocrinol Metab. 2004; 89: 3601-5.

8. Perez-Martinez P, Delgado-Lista J, Garcia-Rios A, Ferguson JF, Gulseth HL, Williams CM, et al. Calpain-10 interacts with plasma saturated fatty acid concentrations to influence insulin resistance in individuals with the metabolic syndrome. Am J Clin Nutr. 2011; 93 : 1136-41.

9. Maleki F, Haghani K, Shokouhi S, Mahmoodi K, Sayehmiri K, Mahdieh $\mathrm{N}$, et al. A case-control study on the association of common variants of CAPN10 gene and the risk of type 2 diabetes in an Iranian population. Clin Lab. 2014; 60: 663-70.

10. Zaharna MM, Abed AA, Sharif FA. Calpain 10 gene polymorphism in type 2 diabetes mellitus patients in Gaza strip. Med Princ Pract. 2010; 19: 457-62.

11. Dita Garnita. Faktor Risiko Diabetes Mellitus di Indonesia (Analisis Data SAKERTI 2007). Jakarta: University Indonesia; 2012.

12. Ezzidi I, Turki A, Messaoudi S, Chaieb M, Kacem M, Al-Khateeb $\mathrm{GM}$, et al. Common polymorphisms of calpain-10 and the risk of Type 2 Diabetes in a Tunisian Arab population: a case-control study. BMC Med Genet. 2010; 11: 75. doi: 10.1186/1471-2350-11-75.

13. Marshall C, Hitman GA, Partridge CJ, Clark A, Ma H, Shearer TR, et al. Evidence that an isoform of calpain-10 is a regulator of exocytosis in pancreatic beta-cells. Mol Endocrinol. 2005;19: 21324.

14. Hatta T, Iemura SI, Ohishi T, Nakayama H, Seimiya H, Yasuda $\mathrm{T}$, et al. Calpain-10 regulates actin dynamics by proteolysis of microtubule-associated protein 1B. Sci Rep. 2018; 8: 16756. doi: 10.1038/s41598-018-35204-x.

15. Loya Méndez Y, Reyes Leal G, Sánchez González A, Portillo Reyes V, Reyes Ruvalcaba D, Bojórquez Rangel G. SNP-19 genotypic variants of CAPN10 gene and its relation to diabetes mellitus type 2 in a population of Ciudad Juarez, Mexico. Nutr Hosp. 2014; 31: 744-50.

16. Gusni S. Deteksi Polimorfisme Delesi/Insersi-19 Gen Calpain 10 (CAPN10) pada Pasien Diabetes Mellitus Tipe 2 Etnis Minangkabau. Padang: Universitas Negeri Padang; 2013.

17. Hamuaty RB, Sukmawati IR, Sandra F. Relationship between sRAGE and hsCRP as markers of cardiovascular disease risk factors in 
diabetic and non-diabetic men with central obesity. Mol Cell Biomed Sci. 2017; 1: 70-4.

18. Hua X, Hong ZX. Effects of individualized prescriptive diet and single prescriptive diet on blood lipids and insulin resistance in type 2 diabetes mellitus patients. Chinese General Practice. 2011; 14: 133-5.

19. Yan YZ, Ma RL, Zhang JY, He J, Ma JL, Pang HR, et al. Association of insulin resistance with glucose and lipid metabolism: ethnic heterogeneity in far Western China. Mediators Inflamm. 2016; 2016: 3825037. doi: 10.1155/2016/3825037.

20. Glass CK, Olefsky JM. Inflammation and lipid signaling in the etiology of insulin resistance. Cell Metab. 2012; 15: 635-45

21. Sears B, Perry M. The role of fatty acids in insulin resistance. Lipids Health Dis. 2015; 14: 121. doi: 10.1186/s12944-015-0123-1.
22. Tursinawati Y, Kartikadewi A, Hakim RF. Association of CAPN10 SNP-19 (rs3842570) polymorphism on fasting plasma glucose, blood pressure and body mass index of Javanese type2 diabetes patients. In: International Conference on Food Science \& Technology. IOP Conference Series: Earth and Environmental Science. 2019; 292: 012031. doi:10.1088/17551315/292/1/012031

23. Meza-Espinoza JP, Leal-Ugarte E, Peralta-Leal V, Flores-Villarreal LE, Picos-Cardenas VJ, Sainz-Gonzalez E, et al. Association of CAPN10 SNP-19 with metabolic traits in Mexican patients with type 2 diabetes. Int J Hum Genet. 2019; 19: 48-53.

24. Hoffstedt J, Näslund E, Arner P. Calpain-10 gene polymorphism is associated with reduced beta(3)-adrenoceptor function in human fat cells. J Clin Endocrinol Metab. 2002; 87: 3362-7. 